\title{
TINDAKAN KOMPRES HANGAT PADA TEMPORAL LOBE DAN ABDOMEN TERHADAP REAKSI SUHU TUBUH PASIEN DENGAN TYPHOID FEVER
}

\section{THE EFFECT OF WARM COMPRESS APPLICATION ON TEMPORAL LOBE AND ABDOMEN IN DECREASING BODY TEMPERATURE AMONG PATIENTS WITH TYPOID FEVER}

\author{
Yunus Elon ${ }^{1}$, Uly Simbolon ${ }^{2}$ \\ Fakultas IImu Keperawatan Universitas Advent Indonesia \\ Email: yunus.elon@unai.edu
}

\begin{abstract}
ABSTRAK
Pendahuluan: Peningkatan suhu tubuh yang tidak ditangani dapat menyebabkan dehidrasi yang akan mengganggu keseimbangan elektrolit serta menyebabkan kejang. Kejang yang berulang akan mengakibatkan kerusakan pada sel otak yang akan meyebabkan gangguan tingkah laku, serta dehidrasi. Dehidrasi yang berat dapat menyebabkan syok yang bisa berakibat fatal hingga berujung kematian. Tujuan: Untuk mengetahui efek dari tindakan kompres hangat pada temporal lobe dan abdomen terhadap reaksi tubuh pasien dengan thyfoid fever. Metode: Penelitian ini menggunakan quasi eksperimental design, dengan menggunakan Two Group PreTest and Post-Test Design. Teknik sampling purposive digunakan untuk memilih partisipan yang secara acak dibagi kedalam dua kelompok intervensi. Dimana kelompok pertama diberi kompres hangat pada Temporal lobe dan kelompok kedua diberi kompres hangat pada abdomen. Hasil: Penelitian ini menunjukan ada perbedaan reaksi penurunan suhu tubuh yang signifikan pada pasien Typhoid Fever sebelum dan sesudah diberikan tindakan kompres hangat pada kedua kelompok. Diskusi: Hasil statistic menunjukkan bahwa pemberian kompres hangat pada temporal lobe dan abdomen sama-sama efektif dalam menurunkan suhu tubuh pada pasien dengan typod fever.
\end{abstract}

Kata Kunci: Suhu Tubuh, Kompres Hangat, Typhoid Fever

\begin{abstract}
Introduction: High body temperature can cause dehydration which can alter electrolyte balance and induce seizure. Recurrent zeizures can cause damage to the brain cells which may later cause disturbance in behavior. Severe dehydration may also lead to shock- a fatal situation that may ensue death. Purpose: To determine the effect of warm compress application on temporal lobe and abdomen in decreasing body temperature among patients with typoid fever. Method: This research utilized a quasi-experimental design using two group's pre-test and post-test design. A purposive sampling technique was used to select participant that randomly divided into 2 group intervention. Participant in the first group applied warm compress on the temporal lobe, while participant in the other group applied warm compress on the obdomen Results: The study shows that there is a significant difference in the reduction of body temperature before and after the application of warm compress on both groups. Discussion: the statistical result shows that applying warm compress on temporal and on abdomen are both effective nursing interventions in decreasing body temperature of patients with thypoid fever.
\end{abstract}

Keywords: Body Temperature, Warm Compress, Typhoid Fever 


\section{PENDAHULUAN}

Typhoid Fever merupakan penyakit infeksi menahun yang dapat terjadi pada anak maupun dewasa. World Health Organitation (WHO) memperkirakan jumlah penderita Typhoid Fever diseluruh dunia mencapai 16-33 juta jiwa dengan 500-600 ribu jiwa kematian tiap tahunnya (Aden, 2010). Typhoid Fever yang disebabkan oleh infeksi bakteri Salmonella Thypi merupakan salah satu kasus tertinggi bagi kesehatan khususnya di Indonesia. Beberapa faktor resiko dari penyakit ini antara lain lingkungan dan perilaku hidup bersih yang rendah, sehingga mengakibatkan tingginya angka kejadian penyakit Typhoid Fever.

Typhoid Fever adalah penyakit infeksi akut yang biasanya menyerang saluran pencernaan dengan gejala yaitu demam lebih dari 7 hari dan gangguan pada saluran pencernaan. Dalam kehidupan sehari-hari penyakit ini sering dikenal dengan nama Tipes atau thypus (Akhsin, 2010).

Menurut Depkes RI (2013), sejak tahun 2010 penderita Typhoid Fever dan paratifoid yang tercatat di Rumah Sakit sebanyak 41.081 kasus, dimana 279 pasien diantaranya meninggal dunia. Di Indonesia, penyakit Typhoid Fever bersifat endemik. Penyakit ini tersebar di seluruh wilayah Indonesia yang memiliki suhu udara $20-23^{\circ} \mathrm{C}$. Pada golongan suhu tersebut bakteri Salmonella Thypi dapat hidup dan berkemabang biak. (Nelwan, 2012). Menurut Sodikin (2012), diperkirakan antara 800-100.000 orang yang terkena penyakit Typhoid Fever setiap tahun. Angka kematian akibat Typhoid Fever di Indoensia pada anak-anak sekitar 2,6\% dan pada orang dewasa sekitar 7,4\% jika dirata-rata menjadi $5,7 \%$ dari total kematian.
Insidensi Typhoid Fever di Indonesia bervariasi di setiap daerah dan biasanya terkait dengan sanitasi lingkungan. Di daerah rural atau daerah yang sebagian besar penduduknya petani seperti Jawa Barat ditemukan 157 kasus per 100.000 penduduk, sedangkan di daerah urban atau daerah yang sebagian besar penduduknya bukan bekerja sebagai petani ditemukan 760-810 per 100.000 penduduk (Widodo. 2009). Salah satu masalah atau gejala yang muncul dari penyakit Typhoid Fever adalah panas. Penderita Typhoid Fever mengalami kenaikan suhu pada minggu pertama, menurun pada pagi hari dan meningkat lagi pada sore dan malam hari. Sifat demam yang remiten ini terjadi akibat siklus agen infeksius yang berkembang pada waktu sore dan malam hari saat metabolisme tubuh menurun sehingga suhu tubuh juga ikut menurun. Mekanisme demam dapat terjadi ketika tubuh mengkompensasi set point "palsu" yang di set oleh bakteri Salmonella thypi.

(Algerina, 2008). Hipertermia jika tidak ditangani dapat menyebabkan dehidrasi yang akan mengganggu keseimbangan elektrolit dan dapat menyebabkan kejang. Kejang berulang dapat menyebabkan kerusakan sel otak yang dapat menyebabkan gangguan tingkah laku, serta dehidrasi yang berat dapat menyebabkan syok dan bisa berakibat fatal hingga berujung kematian (Wijayahadi, 2011).

\section{BAHAN DAN METODE}

Penelitian ini menggunakan quasi eksperimental design, rancangan penelitan menggunakan Two Group PreTest and Post-Test Design pada dua kelompok yang berbeda. Sampel 
penelitian ini adalah pasien dengan Typhoid Fever yang dikumpulakan sesuai kriteria selama bulan FebuariApril, sampel dipilih dengan purposive sampling. Purposive sampling biasa disebut judgement sampling adalah teknik penetapan sempel dengan cara memilih sempel diantara populasi yang sesuai dengan kehendak peneliti (tujuan/masalah dalam penelitian), sehingga sampel yang di ambil tersebut mewakili karakteristik populasi yang telah dikenal sebelumnya.

Pertimbangan karakteristik dalam penelitian adalah sebagai berikut:

1. Subjeknya merupakan seluruh pasien Typhoid Fever dari bulan Febuari-April 2017 yang menjalani perawatan.

2. Subjek penelitian ini adalah pasien dengan Typhoid Fever yang berusia remaja (12-25tahun).

3. Subjeknya merupakan pasien Typhoid Fever yang mengalami peningkatan suhu tubuh $>38^{\circ} \mathrm{C}$ selama >3hari.

4. Subjek yang menggunakan yang menggunakan IV RL 20-30gtt/menit.

5. Subjek yang mendapatkan obat penurun panas dengan dosis yang sama.

6. Subjek yang mendapatkan antibiotik dengan dosis dan kandungan yang sama.

7. Subjek yang tidak menggunakan kortikosteroid.

8. Subjek yang terdiagnosa Typhoid.

9. Subjeknya secara sukarela ikut berpartisipasi dalam penelitian yang akan dilakukan.

Prosedur pengambilan data dan dokumentasi dalam penelitian dilakukan selama dua bulan yaitu bulan Febuari April. Adapun langkah pengumpulan data adalah sebagai berikut:
1. Langkah pertama peneliti meminta izin tertulis dari Dekan Fakultas Ilmu Keperawatan untuk melakukan studi pendahuluan di Rumah Sakit Advent Bandung.

2. Setelah peneliti mendapatkan izin, peneliti memberikam izin tertulis tersebut kepada Kepala Diklat dan Direktur Keperawatan Rumah Sakit Advent Bandung.

3. Setelah itu peneliti datang ke bangsal-bangsal untuk memilih subjek sesuai kriteria-kriteria yang telah ditentukan.

4. Peneliti menjelaskan tujuan kepada subjek yaitu untuk mengetahui perbedaan kompres hangat pada temporal dan abdomen pada pasien Typhoid Fever.

5. Peneliti menjelaskan mengenai prosedur penelitian kepada subjek penelitian.

6. Peneliti melakukan prosedur tindakan kompres hangat.

7. Peneliti menyiapkan alat dan bahan untuk prosedur tindakan kompres air hangat pada temporal atau abdomen.

8. Cuci tangan dengan menggunakan enam langkah.

9. Pasang thermometer air raksa pada aksila pasien selama 15 menit.

10. Cabut thermometer dari aksila pasien.

11. Catat berapa suhu tubuh pasien.

12. Ambil washlap berukuran $17 \times 8 \mathrm{~cm}$ lalu rendam kedalam baskom yang berisi air hangat $40^{\circ} \mathrm{C}$ selama 1 menit lalu diperas $2 \mathrm{x}$ perasan.

13. Letakan washlap tersebut ke daerah temporal atau abdomen selama 20 menit.

14. Setelah 20 menit angkat waslap.

15. Ukur kembali suhu tubuh pasien setelah dilakukan kompres hangat dengan menggunakan termometr air raksa.

16. Catat kembali suhu tubuh pasien. 
Bahan penelitian yang digunakan adalah air hangat dengan suhu $40^{\circ} \mathrm{C}$ dan alatalat yang digunakan dalam penelitian ini adalah sebagai berikut:

1. Washlap berukuran $65 \times 30 \mathrm{~cm}$ yang dilipat $4 \mathrm{x}$ sehingga berukuran $17 \mathrm{x} 8$ $\mathrm{cm}$, sebagai alat kompres yang akan ditempatkan pada temporal lobe dan abdomen pasien.

2. Thermometer air raksa yang telah terkalibrasi, sebagai alat untuk mengukur suhu tubuh pasien per aksila.

3. Alat pengukur suhu air, sebagai alat untuk mengukur suhu air hangat $40^{\circ} \mathrm{C}$

4. Baskom berdiameter $23 \mathrm{~cm}$ dan kedalam $9 \mathrm{~cm}$, sebagai tempat untuk menaruh air hangat.

5. Stopwatch, sebagai alat untuk mengukur waktu ketika dilakukan kompres selama 20 menit.

6. Lembar observasi, sebagai alat untuk mencatat suhu tubuh pasien.

\section{HASIL}

1. Gambaran rata-rata suhu tubuh $\left({ }^{\circ} \mathrm{C}\right)$ dari responden sebelum dan sesudah diberikan tindakan kompres hangat pada temporal lobe.

Tabel 1. Rata-rata suhu tubuh $\left({ }^{\circ} \mathrm{C}\right)$ dari responden sebelum dan sesudah diberikan tindakan kompres hangat pada temporal lobe.

\begin{tabular}{lllll}
\hline $\begin{array}{l}\text { Temperatu } \\
\text { re }\end{array}$ & $\mathrm{n}$ & $\begin{array}{l}\text { Mea } \\
\mathrm{n}\end{array}$ & $\mathrm{SD}$ & $\begin{array}{l}\text { Interpreta } \\
\text { si }\end{array}$ \\
\hline Sebelum & 1 & 38.1 & .10 & Slight \\
& 0 & 5 & 8 & fever \\
Sesudah & 1 & 37.1 & .20 & Normal \\
& 0 & 3 & 0 & \\
\hline
\end{tabular}

$S D=$ Standard deviation

Tabel 1. memperlihatkan rata-rata temperatur sebelum diberi kompres hangat pada temporal lobe $=38.15^{\circ} \mathrm{C}$
$(\mathrm{SD}=.108)(\mathrm{n}=10)$ yang diinterpretasikan sebagai slight fever atau suhu tubuh diatas normal dan sesudah diberikan tindakan kompres hangat pada temporal lobe $=37.13^{\circ} \mathrm{C}(\mathrm{SD}=.200)(\mathrm{n}=10)$ yang diinterpretasikan sebagai tidak demam atau suhu tubuh dalam batasan normal.

2. Gambaran rata-rata suhu tubuh $\left({ }^{\circ} \mathrm{C}\right)$ dari responden sebelum dan sesudah diberikan tindakan kompres hangat pada abdomen.

Tabel 2. Rata-rata suhu tubuh $\left({ }^{\circ} \mathrm{C}\right)$ dari responden sebelum dan sesudah diberikan tindakan kompres hangat pada abdomen

\begin{tabular}{lllll}
\hline $\begin{array}{l}\text { Temperatu } \\
\text { re }\end{array}$ & $\mathrm{n}$ & $\begin{array}{l}\text { Mea } \\
\mathrm{n}\end{array}$ & $\mathrm{SD}$ & $\begin{array}{l}\text { Interpreta } \\
\text { si }\end{array}$ \\
\hline Sebelum & 1 & 38.1 & .11 & Slight \\
& 0 & 3 & 5 & fever \\
Sesudah & 1 & 37.6 & .08 & Sub- \\
& 0 & 5 & 4 & febrile \\
\hline
\end{tabular}

$S D=$ Standard deviation

Tabel 2. memperlihatkan rata-rata temperatur sebelum diberi kompres hangat pada abdomen $=38.13^{\circ} \mathrm{C}$ $(\mathrm{SD}=.115)(\mathrm{n}=10)$ yang diinterpretasikan sebagai demam rendah atau suhu tubuh diatas normal dan sesudah diberikan tindakan kompres hangat pada abdomen $=37,65^{\circ} \mathrm{C} \quad(\mathrm{SD}=.084) \quad(\mathrm{n}=10)$ yang diinterpretasikan sebagai sub-febrile atau suhu tubuh naik sedikit diatas normal.

3. Gambaran perbedaan suhu tubuh sebelum dan sesudah diberikan tindakan kompres hangat pada temporal lobe dan abdomen

Tabel 3. Perbedaan suhu tubuh $\left({ }^{\circ} \mathrm{C}\right)$ dari responden sebelum dan sesudah 
diberikan tindakan kompres hangat pada temporal lobe dan abdomen

\begin{tabular}{|c|c|c|c|c|c|}
\hline $\mathrm{KH}$ & $\mathrm{M}$ & SD & $\mathrm{t}$ & $\begin{array}{l}\text { Sig } \\
(2- \\
\text { tailed } \\
)\end{array}$ & $\begin{array}{l}\text { Interpretas } \\
\mathrm{i}\end{array}$ \\
\hline $\begin{array}{l}\text { T.Tempora } \\
1 \text { Sebelum- } \\
\text { Sesudah }\end{array}$ & $\begin{array}{c}1.0 \\
2\end{array}$ & $\begin{array}{c}.23 \\
4\end{array}$ & $\begin{array}{c}13.7 \\
4\end{array}$ & .000 & Signifikan \\
\hline $\begin{array}{l}\text { T.Abdome } \\
\text { n sebelum- } \\
\text { sesudah }\end{array}$ & .48 & $\begin{array}{c}.07 \\
8\end{array}$ & $\begin{array}{c}19.2 \\
3\end{array}$ & .000 & Signifikan \\
\hline
\end{tabular}

Tabel 3 Memperlihatkan perbedaan suhu tubuh sebelum dan sesudah tindakan kompres hangat pada kelompok Temporal lobe dan Abdomen. Selisih rata-rata mean pada kelompok kompres hangat pada temporal $=1.02(\mathrm{SD}=.234)$, $\mathrm{t}=13.74, \quad p=.000$ yang dinyatakan sebagai perbedaan signifikan. Pada kelompok kompres hangat pada abdomen, selisih rata-rata mean sebelum dan sesudah $=48(\mathrm{SD}=.078) \mathrm{t}=19.23$, $p=.000$ yang di interprestasikan sebagai perbedaan signifikan. Hasil ini menunjukkan bahwa terdapat perbedaan yang signifikan dikedua kelompok antara suhu tubuh sebelum dan sesudah diberi kompres hangat pada temporal lobe dan Abdomen.

\section{PEMBAHASAN}

Partisipan pada kelompok yang menerima kompres hangat pada temporal lobe, maupun kelompok yang menerima kompres hangat pada abdomen, mengalami penurunan suhu tubuh secara signifikan. Namun jika dilihat dari jumlah poin suhu tubuh yang turun, didapati kompres hangat pada temporal lebih besar dibanding kompres hangat pada abdomen. Hal ini terjadi karena pada temporal terdapat vena yang lebih dekat dengan permukaan kulit dibanding dengan vena pada abdomen.
Menurut Widago (2011), Penderita Typhoid Fever akan mengalami peningkatan suhu pada minggu pertama, menurun pada pagi hari dan meningkat lagi pada sore dan malam hari. Bakteri Salmonella typhi yang masuk kedalam tubuh sebagian akan dimusnahkan oleh asam lambung dan sebagian ikut masuk ke usus halus, lalu menembus epitel usus, berkembang biak dan masuk ke dalam kelenjar getah bening. Setelah itu, kuman masuk ke peredaran darah dan masuk ke organ-organ terutama hepar dan susmsum tulang yang dilanjutkan dengan pelepasan bakteri dan endotoksin. Endotoksin yang beredar hingga pada aliran darah sitemik memicu pelepasan protein pirogen endogen (protein dalam sel) yang dapat mempengaruhi pusat pengatur suhu tubuh di dalam otak sehingga muncul hipertermia yang remiten.

Sedangkan menurut Nasrudin (2007), Golongan Salmonella yang menjadi penyebab dari Typhoid Fever imi adalah Salmonella Thyposa basil gram negative yang bergerak dengan bulu getar, tidak bersepora dan sekurang-kurangnya mempunyai tiga macam antigen yaitu: Antigen $\mathrm{O}$ (somatic) terletak pada lapisan luar, yang terdiri dari zat kompleks lipopolisakarisa dan lipid. Sering juga disebut endotoksik, Antigen $\mathrm{H}$ (flagella) terdapat pada flagella, fibriae dan pilin dan Antigen Vi untuk melindungi fagositosit dan struktur kimia protein.

Menurut Widoono (2008) ada beberapa tanda dan gejala yangs sering muncul ketika seseorang terinfeksi Typhoid Fever, salah satunya adalah demam tinggi, suhu di atas $38^{\circ} \mathrm{C}$ biasanya $38,9^{\circ}$ $40,6^{\circ} \mathrm{C}$ (diukur melalui aksila), menggigil, kulit juga menjadi tampak kemerahan, diaphoresis, dan kadang sering juga merasa gelisah atau letargi, 
lidah sering kotor berwarna putih, dan terkadang bradikardi.Jadi dapat disimpulkan bahwa tanda dan gejala yang sering muncul pada penyakit ini adalah demam kurang lebih seminggu, pusing, menggigil, nyeri perut, mual dan muntah, diare dan lidah yang kotor berwarna putih.

Menurut Nelwan (2012), terapi yang digunakan pada Typhoid Fever adalah untuk mencapai keadaan bebas dari demam dan gejala-gejalanya, mencegah komplikasi, dan menghindari kematian. Hal yang terpenting yang perlu dilakukan untuk mencegah kekabuhan adalah memusnahkan secara total bakteri yang menyerang tubuh penderita. Sedangkan Widodo (2009) menemukan 3 penatalaksanaan yang bisa digunakan untuk penyakit Typhoid Fever ini:

1. Istirahat (Rest on bed)

Meningkatkan tirah baring dan dengan perawatan sepenuhnya terhadap makanan dan minuman yang dikonsumsi serta buang air kecil dan buang air besar sangat membantu dan mempercepat proses penyembuhan. Dalam perawatannya juga perlu dijaga kebersihan tempat tidur, pakaian, dan perlengkapan yang digunakan. Posisi tidur pasien juga perlu diperhatikan agar tidak terjadi dekubitus dan pneumonia.

2. Diet

Pemberian diet ini juga sangat penting karena asupan makanan yang kurang akan menurunkan keadaan umum dan gizi pasien akan semakin memburuk dan proses penyembuhan akan menjadi lama. Ada yang berpendapat bahwa usus diistirahatkan dan untuk menghindari komplikasi perdarahan saluran cerna atau perforasi usus maka pasien diberikan bubur saring. Namun ada beberapa peneliti yang menunjukkan bahwa pemberian makan soft diet yaitu nasi lunak dengan lauk pauk yang rendah serat (menghindari sementara sayuran yang berserat) aman bila diberikan pada pasien Typhoid Fever.

3. Pemberian antimikroba

Antimikroba yang sering digunakan untuk pasien Typhoid Fever adalah Kloramfenikol, Tiamfenikol, Kotrimoksazol, Ampisilin dan Amoksisilin, Sefalosporin Generasi Ketiga, Golongan fluorokuinolon, dan Kortikosteroid. Antibiotik golongan fluoroquinolone (ciprofloxacin, ofloxacin, dan pefloxacin) merupakan terapi yang efektif untuk Typhoid Fever yang disebabkan isolat tidak resisten terhadap fluoroquinolone dengan angka kesembuhan klinis sebesar $98 \%$, waktu penurunan demam 4 hari, dan angka kekambuhan dan fecal karier kurang dari $2 \%$. Fluoroquinolone memiliki penetrasi ke jaringan yang sangat baik, dapat membunuh S. typhi intraseluler di dalam monosit/makrofag, serta mencapai kadar yang tinggi dalam kandung empedu dibandingkan antibiotik lain (Nelwan, 2012).

Menurut Susilaningrum (2013), ada beberapa 3 komplikasi yang dapat terjadi pada pasien Typhoid Fever:

1. Perdarahan usus

Perdarahan pada usus secara berlebihan akan menyebabkan terjadinya melena yang dapat disertai dengan nyeri perut ditandai dengan tanda-tanda renjatan.

2. Perforasi usus

Perforasi terjadi pada distal ileum. Perforasi yang tidak disertai Peritonitis hanya dapat ditemukan bila terdapat udara di rongga Peritoneum yaitu pekak hati 
menghilang dan terdapat udara didalam hati dan diafragma pada foto rontgen abdomen yang dibuat dalam keadaan tegak.

3. Peritonitis

Ditemukan gejala abdomen akut, yaitu nyeri perut yang hebat, dinding abdomen yang tegang (defense musculair), dan nyeri tekan.

Kompres dengan air hangat atau suamsuam kuku sangat dianjurkan karena kompres hangat yang paling efektif dalam menurunkan suhu tubuh dibandingkan dengan kompres air dingin atau alcohol. Sistem pengaturan suhu tubuh manusia terdiri atas tiga bagian yaitu reseptor yang terdapat pada kulit dan bagian tubuh lainya, integrator di dalam hipotalamus, dan efektor system yang mengatur produksi panas dan kehilangan panas. Reseptor sensori yang paling sering banyak terdapat pada kulit. Manfaat dari kompres hangat tidak hanya untuk menurunkan suhu tubuh namun salah satunya juga dapat memberikan rasa sangat hangat, nyaman dan tenang pada pasien (Asmadi, 2006). Sedangkan menurut Perry (2010), sinyal hangat yang dibawa oleh darah menuju hipotalamus akan merangsang area preoptik dan mengakibatkan pengeluaran sinyal oleh system efektor. Sinyal ini menyebabkan terjadinya pengeluaran panas tubuh yang lebih banyak melalui dua mekanisme yaitu dilatasi pembuluh darah perifer dan berkeringat.

Pemberian kompres hangat pada daerah pembuluh darah besar merupakan upaya memberikan rangsangan pada area preoptik hipotalamus agar menurunkan suhu tubuh. Sinyal hangat yang dibawa oleh darah ini menuju hipotalamus akan merangsang area preoptik mengakibatkan pengeluaran sinyal oleh sistem efektor. Sinyal ini akan menyebabkan terjadinya pengeluarn panas tubuh yang lebih banyak melalui dua mekanisme yaitu dilatasi pembuluh darah perifer dan berkeringat (Perry, 2010)

Menurut Sherwood (2014), reseptor suhu sangat aktif selama perubahan temperatur. Sensasi suhu primer diadaptasi dengan sangat cepat. Suhu inti dipantau oleh termoreseptor sentral yang terletak di hipotalamus serta di susunan syaraf pusat dan organ abdomen. Termoreseptor ini terletak diantara hipotalamus anterior, medulla spinalis, organ abdomen dan struktur internal lainnya juga mendeteksi perubahan suhu darah. Hipotalamus terus-menerus mendapat informasi mengenai suhu kulit dan suhu inti melalui reseptor khusus yang peka terhadap suhu yang disebut termoreseptor (reseptor hangat, dingin dan nyeri di perifer). Reseptor suhu sangat aktif selama perubahan temperatur. Sensasi suhu primer diadaptasi dengan sangat cepat. Suhu inti dipantau oleh termoreseptor sentral yang terletak di hipotalamus serta di susunan syaraf pusat dan organ abdomen.

Sedangkan menurut Perry (2010), sinyal hangat yang dibawa oleh darah menuju hipotalamus akan merangsang area preoptik dan mengakibatkan pengeluaran sinyal oleh system efektor. Sinyal ini menyebabkan terjadinya pengeluaran panas tubuh yang lebih banyak melalui dua mekanisme yaitu dilatasi pembuluh darah perifer dan berkeringat.

\section{KESIMPULAN}

Kesimpulan dari hasil penelitian ini adalah:

1. Hasil statistik menunjukan bahwa suhu tubuh pasien sebelum dilakukan tindakan kompres hangat pada temporal lobe (kelompok A) 
adalah $38,14^{\circ} \mathrm{C}$ yang berarti demam sedang dan sesudah diberikan tindakan kompres hangat pada temporal mengalami penurunan menjadi $37,09^{\circ} \mathrm{C}$ yang dikategorikan sebagai suhu tubuh normal.

2. Hasil statistik menunjukan suhu tubuh pasien sebelum dilakukan tindakan kompres hangat pada abdomen (kelompok B) adalah $38,13^{\circ} \mathrm{C}$ yang berarti demam sedang dan sesudah diberikan tindakan kompres hangat pada abdomen mengalami penurunan menjadi $37,65^{\circ} \mathrm{C}$ yang dikategorikan sebagai demam ringan.

3. Ada perbedaan reaksi penurunan suhu tubuh yang signifikan pada pasien Typhoid Fever sebelum dan sesudah diberikan tindakan kompres hangat pada kedua grup. Hasil tersebut memperlihatkan bahwa pemberian kompres hangat pada temporal lobe dan abdomen tersebut sama-sama efektif dalam menurunkan suhu tubuh terutama kompres hangat pada temporal.

\section{DAFTAR PUSTAKA}

Aden, R. (2010). Seputar Penyakit dan Gangguan Lain Pada Anak. Yogyakarta: Siklus Hanggar Kreator.

Akhsin, Zulkoni. (2010). Parasitologi. Yogyakarta: Nuha Medika.

Algerina. (2008). Tifoid Pada Anak. Jakarta: $\quad$ Elex Media Komputindo.

Arikunto, Suharsimi. (2010). Prosedur Penelitian Suatu Pendekatan Praktek. Jakarta: Penerbit Rineka Cipta
Asmadi. (2008). Teknik Procedural Keperawatan Konsep dan Aplikasi Kebutuhan Dasar Klien. Jakarta: Salemba Medika.

Depkes RI. (2013). Sistematika Pedoman Pengendalian Penyakit Demam Tifoid. Jakarta: Direktorat Jendral Pengendalian Penyakit \& Penyehatan Lingkungan.

Nasrudin. (2007). Penyakit Infeksi di Indonesia. Surabaya: Airlangga Univercity Press.

Nelwan, R.H.H. (2012). Tata Laksana Terkini Demam Tifoid. Divisi Penyakit Tropik dan Infeksi Departemen Ilmu Penyakit Dalam, Jakarta: FKUI/RSCM

Potter, A.P., \& Perry, G.A., (2010). Fundamental Keperawatan, Edisi 7, Buku 2. Jakarta: Salemba Medika

Rutoto, S. (2007). Pengantar Metedologi Penelitian. FKIP: Universiatas Muria Kudus

Sherwood, Lauralee, (2014). Fisiologi Manusia: Dari Sel Ke Sistem Ed. 8, Jakarta: EGC.

Sodikin. (2012). Prinsip perawatan demam pada anak. Yogjakarta: Pustaka Belajar.

Susilaningrum, Rekawati, Nursalam, Utami \& Sri. (2013). Asuhan Keperawatan Bayi dan Anak. Jakarta: Salemba Medika.

Widagdo. (2011). Masalah dan Tatalaksana Penyakit Infeksi Pada Anak. Jakarta: Sagung Seto. 
Widagdo. (2012). Masalah dan Tatalaksana Penyakit Anak dengan Demam. Jakarta: Sagung Seto.

Widodo, J. (2006). Demam Tifoid, Buku Ajar Ilmu Penyakit Dalam. Jakarta: Pusat Penerbitan Departemen Ilmu Penyakit Dalam FKIU.

Widodo D. (2009) Demam Tifoid. In: Sudoyo AW, editor. Buku Ajar Ilmu Penyakit Dalam Jilid III. Jakarta: Interna Publishing.

Wijayahadi, dkk. (2011). Faktor Risiko Bangkitan Kejang Demam pada Anak. Sari Pediatri. Volume 2, Nomor 3. 